UDC 631.8: 161.169 .2

\title{
EFFECT OF POLYMERIC BIOCIDE POLYHEXAMETHYLENE GUANIDINE HYDROCHLORIDE ON MORPHO-PHYSIOLOGICAL AND BIOCHEMICAL PARAMETERS OF WHEAT SEEDLINGS UNDER COPPER STRESS
}

\author{
L. G. Lyoshyna ${ }^{1}$, O. P. Tarasyuk ${ }^{2}$, O. V. Bulko ${ }^{1}$, S. P. Rogalsky ${ }^{2}$, \\ T. M. Kamenieva ${ }^{2}$, M. V. Kuchuk ${ }^{1}$ \\ ${ }^{1}$ Institute of Cell Biology and Genetic Engineering, NAS of Ukraine \\ 148, Akademika Zabolotnoho Str., Kyiv, 03143, Ukraine \\ ${ }^{2}$ V. P. Kukhar Institute of Bioorganic Chemistry and Petrochemistry, NAS of Ukraine \\ 50, Kharkivske shosse, Kyiv, 02160, Ukraine \\ E-mail: llioshina@ukr.net
}

Received October 24, 2019 / Received February 20, 2020 / Accepted March 20, 2019

\begin{abstract}
Aim. To study the effect of polymeric biocide polyhexamethylene guanidine hydrochloride (PHMG-Cl) on morphophysiological and biochemical parameters of wheat seedlings in the presence of toxic concentration of copper ions. Methods. The growth-stimulating activity of PHMG-Cl in pure state, as well as in the presence of elevated concentrations of copper ions was studied by phytotesting method using wheat seed as a test culture. Physico-chemical interaction between PHMG-Cl and $\mathrm{CuSO}_{4}$ in water solutions was studied by spectrophotometry. Results. Wheat seed treatment with water solutions of polymeric biocide PHMG-Cl in the concentration range of $0.01-0.1 \%$ causes an increase in the length of roots and shoots by over $50 \%$ after 7 days of incubation. The concentration of PHMG-Cl of 1 $\%$ was found to have a depressive effect on growth characteristics of the tested plants. This fact indicates that the phytotoxicity of PHMG-Cl is at least two orders of magnitude lower compared with a common pesticide copper sulfate. Thus, wheat seed soaking in $200 \mu \mathrm{M}(0.003 \%)$ water solution of copper sulfate causes reduced length of shoots and roots (by 65 and $34 \%$, respectively), as well as reduced weight of shoots (by $20 \%$ ) and roots (by $74 \%$ ) The analysis of green mass showed significantly reduced content of carotenoids (by $26 \%$ ) and water soluble flavonoids (by $37 \%$ ), as well as chlorophyll $a / b$ ratio (by $18 \%$ ) that indicates decreased plant metabolic activity. However, the toxic effect of copper sulfate ions significantly diminished in the presence of PHMG-Cl $(0.01 \%)$. Thus, the length of shoots and roots was found to increase by 24 and $64 \%$, respectively, compared to the samples treated with $\mathrm{CuSO}_{4}$. Moreover, the content of pigments and flavonoids in the green mass of seedlings reached the level of control samples. The results of spectrophotometric studies indicate the absence of physico-chemical interaction between PHMG-Cl and copper sulfate in water solutions. Conclusions. The polymeric biocide PHMG-Cl effectively stimulates growth and development of wheat seedlings in the concentration range of its water solutions of $0.01-0.1 \%$. In the presence of toxic copper sulfate concentration, PHMG-Cl does not possess the growth stimulating activity. However, the polymeric biocide significantly improves copper stress resistance of plants, and normalizes their morpho-physiological indicators, photosynthetic characteristics and secondary exchange.
\end{abstract}

Key words: wheat, seeds, polymeric biocide, polyhexamethylene guanidine, growth stimulation, phytotoxicity, stress factor, copper.

DOI:

\section{INTRODUCTION}

Polymeric onium salts or cationic polymers are promising biocides, combining a wide spectrum of antimicrobial activity against bacteria and fungi with moderate ecotoxicity (Zhou Z et al 2011, CarmonaRibeiro AM, de Melo Carrasco LD 2013, Choi H et al 2017, Protasov A et al, 2017, Olmedo et al, 2018). Practical application has been found for salts of poly- 
hexamethylene guanidine (PHMG), containing guanidinium cations in the polymer backbone. Water solutions of PHMG hydrochloride (PHMG-Cl) have been used as efficient disinfectants in the cooling systems, swimming pools, medical institutions and veterinary medicine, wood protection, etc. (Zhou Z et al, 2011, Choi $\mathrm{H}$ et al, 2017, Olmedo et al, 2018).

Patent RU 2328854 (Filonik IA, Aprasjukhin AI 2008) reported the application of PHMG-Cl to stimulate the growth and development of cereals and legumes. It was established that pre-sowing treatment of wheat and corn seed with diluted water solutions of PHMG-Cl in the concentration of $0.01-0.05 \%$ stimulated the increase in the growth indices of the seedlings by $10-50 \%$, enhanced grain yield, as well as improved plant resistance to pathogenic microflora. It has been found that PHMG salt with succinic acid, a known plant growth stimulator, has enhanced growth promoting effect on peas, rye, beets and corn seed growth (Lysytsya A et al 2013). The substances may have inhibiting (biocidal) or stimulating effect on seeds depending on concentration. Another article (Yessimova OA et al 2018) reports growthpromoting effect of PHMG-Cl on vegetables. The treatment of tomato seeds with water solutions of the polymeric biocide in the concentrations of $0.01-$ $0.05 \%$ increased the length of the seedling stem and roots by $50-60 \%$.

Thus, the results of recent studies demonstrate the availability of PHMG salts as complex preparations to stimulate the growth of plants and protect them from pathogenic microorganisms. However, it is noteworthy that ecotoxicity of onium salts and their ability to biodegradation are critically relevant factors, defining the usability of these substances for agronomy. It is known that PHMG-Cl has bacteriostatic effect in the concentrations of order $10^{-4} \%$ and bactericidal activity at $10^{-3}$ \% (Zhou Z et al 2011, Lysytsya A 2017, Lysytsya A et al 2017). The substance is moderately toxic for freshwater hydrobionts (Protasov A et al 2016), safe concentration for them is $10^{-4} \%$. The plant constituent of water biocenoses endures the doses of polymeric biocide up to $10^{-3} \%$ (Lysytsya $\mathrm{A}$ et al 2017). The PHMG-Cl transfer coefficient into plant from water was found to be $0.1 \%$, whereas the transfer coefficient from soil or plant surface into inner tissues is $0.01 \%$ (Lysytsya A 2017). The authors explain this fact by efficient adsorption of polymeric biocide by soil components, which limits the possibility of its migration along nutrition chains. A relevant advantage of PHMG-Cl is the ability to biological degradation under the impact of some soil bacteria and microorganisms of active sludge.

The study on the growth-stimulating activity of cationic polymers under conditions of toxic pollution of soil with heavy metals is of special interest, and copper takes a particular place therein. This metal belongs to essential elements, whose microamounts play a key role in photosynthetic and respiratory electron transport chains, in ethylene sensing, cell wall metabolism and oxidative stress protection, and whose excess triggers morpho-physiological changes - root growth inhibition, chlorosis of leaves and general growth inhibition (Yruela I 2009). Due to a wide spectrum of biocidal activity against phytopathogens, copper compounds are commonly used in agriculture as micronutrients and plant protection products (Lamichhane JR et al, 2018). However, long-term application of copper-containing pesticides in large volumes leads to their excessive accumulation in soil and water bodies, and thus, harmful impact on the environment. Particularly, they may pose a potential hazard to freshwater hydrobionts - shellfish, crustaceans, fish (Husak V 2015). It has been established that copper compounds have bactericidal effect on various microorganisms of soil and water bodies - they inhibit soil microflora and processes of mineralization of organic substances (Lamichhane JR et al 2018). It should be noted that the study of growthpromoting activity of nitrogen-containing compounds in soils contaminated with copper salts gets complicated by both negative impact of the latter on the growth of plants and by possible physico-chemical interaction between $\mathrm{Cu}^{2+}$ ions and active molecules.

The aim of this work was to determine the effect of polymeric biocide PHMG-Cl on growth and physiological characteristics of wheat seedlings under copper stress.

\section{MATERIALS AND METHODS}

Polymeric biocide PHMG-Cl was synthesized by the method, described in the work (Protasov A et al 2017) (Fig. 1).

Water solutions of PHMG-Cl and $\mathrm{CuSO}_{4}$ mixtures were spectrophotometrically analyzed at Jenway 6850 instrument (Great Britain) in the range of 190-1000 $\mathrm{nm}$.

The efficiency of germination (\%) was determined using a test-culture of winter wheat Podolianka as the ratio between the number of germinated seeds and their total number. Wheat seeds were soaked in aqueous solutions of $\mathrm{PHMG}-\mathrm{Cl}$ for one hour, placed into Petri 


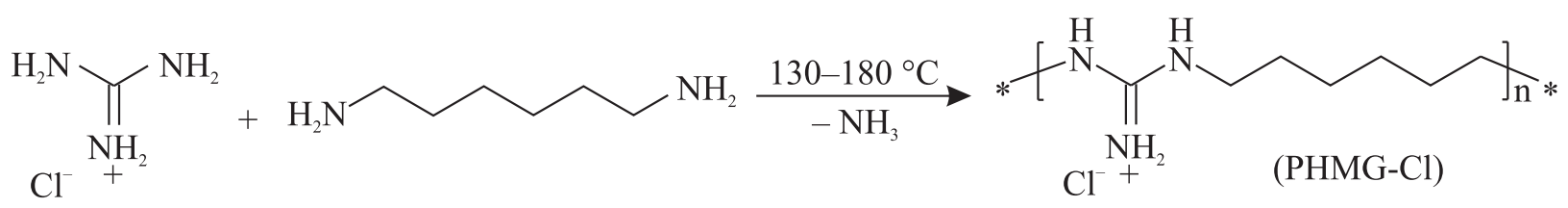

Fig. 1. Synthesis of polymeric biocide PHMG-Cl

dishes and germinated on filters, moistened with distilled water. Primary root length (L) and shoot length (1) was measured on 3- and 7-days-old-seedlings. The incubation of wheat seeds was conducted in a dark place at the temperature of $22 \pm 2{ }^{\circ} \mathrm{C}$ and air humidity of 70-90\%. Germinated seeds were placed under diffuse daylight.

The estimation of the detoxication of copper ions was conducted by phytotesting (Xia X, Shen ZG 2007, Adrees $M$ et al 2015). This included determination of wheat seed germination, the mass of dry and wet matter, water content and the number of photosynthetic pigments and phenol compounds in the roots and green mass of test plants. Copper ions were introduced in the form of aqueous solution of $\mathrm{CuSO}_{4}$ with the concentration of $200 \mu \mathrm{mol} / 1$ into aqueous solutions of PHMG$\mathrm{Cl}$, the concentrations of which were $0.01,0.1,0.5$ and $1.0 \%$. Forty wheat seeds were soaked in the solution of the given concentration for one hour, then placed on two layers of the filtration paper with the addition of $3 \mathrm{ml}$ of water. The incubation was conducted at $22{ }^{\circ} \mathrm{C} \pm 1$. The analysis was performed in three days.

The quantitative estimation of chlorophyll $a$ and $b$ and carotenoid content $(\mathrm{Ca}, \mathrm{Cb}, \mathrm{Ccar})$ as well as chlorophyll $a / b$ ratio $(\mathrm{C} a / \mathrm{C} b)$ was conducted using a Fluorat-02-Panorama spectrofluometer (Russia) by measuring the absorption of the ethanol extract of pigments at wavelength of 649 and $665 \mathrm{~nm}$ which are characteristic peaks of chlorophylls and at $479 \mathrm{~nm}$ which is characteristic peak of carotenoids (Lichtenthaler HK 1987). The content of flavonoids (Cfl) was determined by the method, based on light absorption by a complex of flavonoids with aluminum chloride (III) at the wavelength of $415 \mathrm{~nm}$, calculated per standard solution of rutin (Lioshyna et al 2017). The optical density of the solution was measured at $415 \mathrm{~nm}$. The base solution was a sample, containing ethanol instead of the extract from plant tissue. The device was preliminarily calibrated by $1 \%$ rutin solution.

The statistical processing and analysis of the experimental data were conducted in Excel application of the standard Microsoft Office XP package (Microsoft, USA). If the samplings were subject to the normal distribution law, Student's T-test was used for their comparison. The obtained results were considered reliable at the significance level, set at $\mathrm{p}<0.05$.

\section{RESULTS}

Table 1 presents growth characteristics of wheat seedlings after their treatment with aqueous solutions of PHMG-Cl. After three days, growth parameters for control samples and for seeds, treated with diluted solutions of polymeric biocide $(0.001-0.1 \%)$, differed only slightly. The concentration of PHMG-Cl of $1 \%$ inhibited the growth of roots and shoots significantly.

Table 1. Wheat seeds germination after treatment with water solutions of PHMG-Cl

\begin{tabular}{|c|c|c|c|c|c|c|c|c|c|}
\hline \multirow{3}{*}{$\begin{array}{l}\text { PHMG-Cl } \\
\text { concentra- } \\
\text { tion, } \%\end{array}$} & \multirow{3}{*}{$\begin{array}{c}\text { Germina- } \\
\text { tion/control, } \\
\%\end{array}$} & \multicolumn{4}{|c|}{ Root length } & \multicolumn{4}{|c|}{ Shoot length } \\
\hline & & \multicolumn{2}{|c|}{3 days } & \multicolumn{2}{|l|}{7 days } & \multicolumn{2}{|l|}{3 days } & \multicolumn{2}{|l|}{7 days } \\
\hline & & $\begin{array}{c}(\mathrm{M} \pm \mathrm{m} \\
\mathrm{n}=9), \mathrm{mm}\end{array}$ & $\%$ & $\begin{array}{c}(\mathrm{M} \pm \mathrm{m} \\
\mathrm{n}=9), \mathrm{mm}\end{array}$ & $\%$ & $\begin{array}{c}(\mathrm{M} \pm \mathrm{m} \\
\mathrm{n}=9), \mathrm{mm}\end{array}$ & $\%$ & $\begin{array}{c}(\mathrm{M} \pm \mathrm{m} \\
\mathrm{n}=9), \mathrm{mm}\end{array}$ & $\%$ \\
\hline Control $\left(\mathrm{H}_{2} \mathrm{O}\right)$ & 100.0 & $41.1 \pm 1.34$ & 100.0 & $48.5 \pm 0.45$ & 100.0 & $31.5 \pm 1.45$ & 100.0 & $57.0 \pm 1.18$ & 100 \\
\hline $0.001 \%$ & 97.7 & $39.7 \pm 0.84$ & 96.5 & $58.4 \pm 0.99^{*}$ & 120,1 & $36.1 \pm 1.31 *$ & 114.6 & $59.6 \pm 0.74$ & 104.6 \\
\hline $0.01 \%$ & 100.2 & $41.4 \pm 0.93$ & 100.7 & $76.6 \pm 1.12 *$ & 157.9 & $28.5 \pm 1.76 *$ & 90.5 & $83.9 \pm 0.84 *$ & 147.2 \\
\hline $0.1 \%$ & 95.2 & $38.4 \pm 1.01$ & 93.4 & $74.1 \pm 1.00 *$ & 152.8 & $24.7 \pm 0.85 *$ & 78.4 & $74.7 \pm 1.22 *$ & 131.0 \\
\hline $1 \%$ & 92.3 & $25.2 \pm 1.14^{*}$ & 61.3 & $38.0 \pm 0.94 *$ & 78.3 & $6.0 \pm 1.11 *$ & 19.0 & $58.0 \pm 1.21$ & 101.7 \\
\hline
\end{tabular}

Note. The asterisks represent that the values are significantly different from the corresponding control values. 
After seven days, the length of roots of the seedlings, soaked in the solutions of PHMG-Cl with the concentration of 0.01 and $0.1 \%$, was much higher compared to control samples (by 57 and $52 \%$, respectively.) A similar effect was observed for the shoots (the increase in the length by 47 and $31 \%$ compared to the control).

The morpho-physiological characteristics of wheat seedlings treated with aqueous solutions of copper sulfate and $\mathrm{CuSO}_{4} / \mathrm{PHMG}-\mathrm{Cl}$ mixtures are presented in Table 2. The obtained results indicate significant inhibition of seedlings growth after seed treatment with the solution of copper sulfate. This was manifested in terms of reduced shoot length (by $34 \%$ ) and root length (by $65 \%$ ), compared to control samples (control 1). The introduction of $\mathrm{PHMG}-\mathrm{Cl}$ in $\mathrm{CuSO}_{4}$ solution in the concentrations of 0.01 and $0.1 \%$ enhanced growth characteristics of the roots (by 40 and $15 \%$, respectively) and the green part of seedlings (by 20 and 15 $\%$ ) compared to the control 2. The increase of PHMG$\mathrm{Cl}$ concentration up to $1 \%$ inhibited the growth indices compared to the seeds treated with the solution of $\mathrm{CuSO}_{4}$.
According to the data in Table 3, the presence of copper ions in the solution in the concentration of $200 \mu \mathrm{mol} / 1$ reduces the relative content of water in the roots of wheat seedlings by $9.8 \%$ which is a relevant index of water deficiency. As for the green part, this index practically did not change and remained at the control level. The mass of the roots and green part of the shoots decreased by 74 and $20 \%$, respectively, which confirmed the inhibition of physiological processes under the impact of $\mathrm{Cu}^{2+}$ ions. The toxic effect of copper sulfate decreased in the presence of PHMG-Cl (0.1\%). This was manifested in terms of the increased shoot mass compared to control indices (control 1), as well as increased root mass by $36 \%$ compared to the control 2 (Table 3).

The informative indices to characterize the work of the synthetic apparatus of plants is the pigment content (chlorophyll $a$ and $b$, carotenoids) and chlorophyll $a / b$ ratio. The data shown in Table 4 demonstrate that the treatment of wheat seeds with the solution of $\mathrm{CuSO}_{4}$ leads to significant reduction of pigment content, namely, chlorophylls a and $b$, and carotenoids. The change

Table 2. Wheat germination after treatment with water solutions of $\mathrm{PHMG}-\mathrm{Cl}$ and $\mathrm{CuSO}_{4}$

\begin{tabular}{l|c|c|c|c|c|c}
\hline \multirow{2}{*}{ Solutions } & \multicolumn{3}{|c|}{ Shoot length (3 days) } & \multicolumn{3}{c}{ Root length (3 days) } \\
\cline { 2 - 7 } & $\begin{array}{c}(\mathrm{M} \pm \mathrm{m}, \\
\mathrm{n}=9), \mathrm{mm}\end{array}$ & $\begin{array}{c}\text { \% of the } \\
\text { control 1 }\end{array}$ & $\begin{array}{c}\% \text { of the } \\
\text { control } 2\end{array}$ & $\begin{array}{c}(\mathrm{M} \pm \mathrm{m}, \\
\mathrm{n}=9), \mathrm{mm}\end{array}$ & $\begin{array}{c}\text { \% of the } \\
\text { control 1 }\end{array}$ & $\begin{array}{c}\% \text { of the } \\
\text { control 2 }\end{array}$ \\
\hline Control 1 $\left(\mathrm{H}_{2} \mathrm{O}\right)$ & $29.9 \pm 1.68 *$ & 100 & 151.7 & $24.3 \pm 1.17 *$ & 100 & 290.3 \\
$\mathrm{Control} 2\left(\mathrm{Cu}^{2+}\right)$ & $19.7 \pm 1.19$ & 65.8 & 100.0 & $8.37 \pm 0.91$ & 34.4 & 100.0 \\
$\mathrm{Cu}^{2+} /$ PHMG-Cl $(0.01 \%)$ & $24.6 \pm 0.64 *$ & 82.3 & 124.8 & $13.8 \pm 0.77 *$ & 56.8 & 164.8 \\
$\mathrm{Cu}^{2+} /$ PHMG-Cl $(0.1 \%)$ & $23.2 \pm 1.19 *$ & 77.6 & 117.8 & $9.78 \pm 0.93 *$ & 40.2 & 116.8 \\
$\mathrm{Cu}^{2+} /$ PHMG-Cl $(0.5 \%)$ & $14.5 \pm 0.26 *$ & 48.5 & 73.6 & $9.39 \pm 0.83$ & 38.6 & 112.2 \\
$\mathrm{Cu}^{2+} /$ PHMG-Cl $(1 \%)$ & $9.15 \pm 0.15$ & 30.6 & 46.4 & $3.77 \pm 1.02 *$ & 15.5 & 45.0 \\
\hline
\end{tabular}

Note. in the table 2,3,4 asterisks indicate values that significantly $(\mathrm{p} \leq 0.05)$ differ from the indicators of the control 2

Table 3. The effect of PHMG-Cl on the mass and water content in the cells of wheat seedlings in the presence of $\mathrm{CuSO}_{4}$

\begin{tabular}{l|c|c|c|c|c|c}
\hline \multirow{2}{*}{ Solutions } & \multicolumn{3}{|c|}{ Green mass } & \multicolumn{3}{c}{ Root } \\
\cline { 2 - 7 } & $\begin{array}{c}\mathrm{M}_{\text {wet }}, \mathrm{g} \\
(\mathrm{M} \pm \mathrm{m}, \mathrm{n}=9)\end{array}$ & $\begin{array}{c}\mathrm{M}_{\text {dry }}, \mathrm{g} \\
(\mathrm{M} \pm \mathrm{m}, \mathrm{n}=9)\end{array}$ & $\begin{array}{c}\text { Hydra- } \\
\text { tion, \% }\end{array}$ & $\begin{array}{c}\mathrm{M}_{\text {wet }} \mathrm{g} \\
(\mathrm{M} \pm \mathrm{m}, \mathrm{n}=9)\end{array}$ & $\begin{array}{c}\mathrm{M}_{\text {dry }} \mathrm{g} \\
(\mathrm{M} \pm \mathrm{m}, \mathrm{n}=9)\end{array}$ & $\begin{array}{c}\text { Hydra- } \\
\text { tion, \% }\end{array}$ \\
\hline $\mathrm{Control} 1\left(\mathrm{H}_{2} \mathrm{O}\right)$ & $0.72 \pm 0.07 *$ & $0.083 \pm 0.02 *$ & 88.5 & $0.61 \pm 0.08 *$ & $0.089 \pm 0.02 *$ & 85.4 \\
$\mathrm{Control} 2\left(\mathrm{Cu}^{2+}\right)$ & $0.58 \pm 0.04$ & $0.074 \pm 0.01$ & 87.2 & $0.16 \pm 0.1$ & $0.039 \pm 0.02$ & 75.6 \\
$\mathrm{Cu}^{2+} / \mathrm{PHMG-Cl}(0.01 \%)$ & $0.61 \pm 0.06$ & $0.06 \pm 0.01$ & 90.2 & $0.23 \pm 0.05 *$ & $0.048 \pm 0.01$ & 79.1 \\
$\mathrm{Cu}^{2+} / \mathrm{PHMG-Cl}(0.1 \%)$ & $0.75 \pm 0.06 *$ & $0.097 \pm 0.03 *$ & 87.1 & $0.36 \pm 0.04 *$ & $0.069 \pm 0.03 *$ & 80.9 \\
$\mathrm{Cu}^{2+} /$ PHMG-Cl $(0.5 \%)$ & $0.52 \pm 0.08$ & $0.068 \pm 0.02$ & 86.9 & $0.21 \pm 0.03$ & $0.051 \pm 0.01 *$ & 75.7 \\
$\mathrm{Cu}^{2+} /$ PHMG-Cl $(1 \%)$ & $0.34 \pm 0.02 *$ & $0.047 \pm 0.04 *$ & 86.2 & $0.09 \pm 0.07 *$ & $0.027 \pm 0.02 *$ & 70.1 \\
\hline
\end{tabular}


in $\mathrm{Ca} / \mathrm{Cb}$ ratio which is an index of photosynthetic capacity of a plant, indicates the impairment of pigment biosynthesis (Pätsikkä E et al 2002). At the same time, the introduction of PHMG-Cl in the concentrations of $0.01-0.05 \%$ restored chlorophyll $a / b$ ratio to the level of control indices, and under the impact of polymeric biocide with the concentration of $1 \%$ the photosynthetic capacity increased significantly (Table 4).

Carotenoids play a relevant role in the photosynthesis by transmitting the light energy they absorb to chlorophyll. Carotenoids also perform protective functions, in particular, prevent destructive photooxidation of organic substances of protoplasm in the presence of light and free oxygen. Thus, their amount may serve as an index of plant stress (Wang $\mathrm{H}$ et al. 2018). Under experimental conditions, the effect of copper ions is manifested in the reduction of total carotenoid content by $26 \%$ compared to the control. The presence of PHMG-Cl in the concentrations of $0.01-0.05 \%$ mitigated the toxic impact of copper sulfate and restored the carotenoid content to the level of control values. Under the impact of polymeric biocide with the concentration of $1 \%$ the content of carotenoids reduced by $46 \%$ compared to the control, which demonstrated stress effect on plants. The ratio of the total amount of chlorophylls $a$ and $b$ and the number of carotenoids $(\mathrm{Ca}+\mathrm{Cb}) / \mathrm{Ccar}$ at norm is a constant value, which is very sensitive to the change of environmental factors (Prasad M N V, Strzałka K 2002). As one can see from the data in Table 4, this ratio changed significantly under the impact of copper sulfate solution and combined solution of $\mathrm{CuSO}_{4} /$ PHMG-Cl (1\%) as compared with the control.

Stress in plants is known to enhance biosynthesis of phenol compounds as components, capable of binding reactive oxygen species (Sharma A et al. 2019). Significant reduction of the content of low molecular antioxidants - flavonoids under the impact of $\mathrm{Cu}^{2+}$ ions (by $47 \%$ ) was determined in the green part of the seedlings, which demonstrated the decrease in the metabolic activity. However, in the samples, treated with the solutions of $\mathrm{CuSO}_{4} / \mathrm{PHMG}-\mathrm{Cl}$, the content of flavonoids was close to the control values. The analysis of roots gave opposite results - the synthesis of flavonoids was enhanced under the impact of the solution of pure copper sulfate and in the presence of PHMG-Cl (Table 4) which demonstrated the stress impact on the roots as an absorbing part of the plant.

The physico-chemical interaction between $\mathrm{CuSO}_{4}$ and PHMG-Cl was studied spectrophotometrically. Fig. 2 contains UV-visible spectra of water solutions of PHMG-Cl in a pure form (1) and in the presence of $\mathrm{CuSO}_{4}$ (curves 2, 3). The absorption peak of guanidine groups is at the wavelength of $192 \mathrm{~nm}$ (Wei D et al 2013). As one can see from Fig. 2, the introduction of copper sulfate to $\mathrm{PHMG}-\mathrm{Cl}$ solution in the molar ratios of $\mathrm{CuSO}_{4} / \mathrm{PHMG}^{-\mathrm{Cl}} 1: 2$ (curve 2) and $1: 1$ (curve 3) does not impact the position of this peak. Fig. 3 contains UV-visible spectra of copper sulfate solution, the peak of absorption for which is at $809 \mathrm{~nm}$ (curve 2). The presence of $\mathrm{PHMG}-\mathrm{Cl}$ in the solution in the molar ratio to $\mathrm{CuSO}_{4}$ of $2: 1$ (curve 3 ) and $1: 1$ (curve 4) does not cause any changes in the spectrum.

\section{DISCUSSION}

In general, the obtained results indicate the growthstimulating effect of PHMG-Cl on wheat seedlings in the concentration range of $0.001-0.1 \%$, at which it also shows bactericidal activity (Zhou Z et al 2011, Lysytsya A et al 2015). It confirms the assumption about different biochemical and biophysical mechanisms of

Table 4. The effect of PHMG-Cl on the pigment composition and number of flavonoids in wheat seedlings in the presence of $\mathrm{CuSO}_{4}$

\begin{tabular}{|c|c|c|c|c|c|c|c|}
\hline Seedlings & $\begin{array}{c}\mathrm{C} a \mathrm{mg} / \mathrm{g} \\
(\mathrm{M} \pm \mathrm{m} \\
\mathrm{n}=9)\end{array}$ & $\begin{array}{c}\mathrm{C} b \mathrm{mg} / \mathrm{g} \\
(\mathrm{M} \pm \mathrm{m} \\
\mathrm{n}=9)\end{array}$ & $\mathrm{C} a / \mathrm{C} b$ & $\begin{array}{c}\text { Ccar } \mathrm{mg} / \mathrm{g} \\
(\mathrm{M} \pm \mathrm{m} \\
\mathrm{n}=9)\end{array}$ & $\begin{array}{c}(\mathrm{C} a+ \\
+\mathrm{C} b)^{\prime} \\
\mathrm{C} c a r\end{array}$ & $\begin{array}{c}\text { Cfl } \mathrm{mg} / \mathrm{g} \\
\text { (green part) } \\
(\mathrm{M} \pm \mathrm{m} \\
\mathrm{n}=9)\end{array}$ & $\begin{array}{c}\text { Cfl } \mathrm{mg} / \mathrm{g} \\
\text { (roots) } \\
(\mathrm{M} \pm \mathrm{m} \\
\mathrm{n}=9)\end{array}$ \\
\hline Control $1\left(\mathrm{H}_{2} \mathrm{O}\right)$ & $0.31 \pm 0.05$ & $0.16 \pm 0.03$ & 1.94 & $3.53 \pm 0.07 *$ & 0.13 & $0.56 \pm 0.02 *$ & $0.05 \pm 0.01 *$ \\
\hline Control $2\left(\mathrm{Cu}^{2+}\right)$ & $0.29 \pm 0.04$ & $0.18 \pm 0.04$ & 1.6 & $2.62 \pm 0.01$ & 0.18 & $0.35 \pm 0.06$ & $0.07 \pm 0.01$ \\
\hline $\mathrm{Cu}^{2+} / \mathrm{PHMG}-\mathrm{Cl}(0.01 \%)$ & $0.33 \pm 0.06$ & $0.18 \pm 0.07$ & 1.83 & $3.48 \pm 0.04 *$ & 0.15 & $0.53 \pm 0.08 *$ & $0.07 \pm 0.04$ \\
\hline $\mathrm{Cu}^{2+} / \mathrm{PHMG}-\mathrm{Cl}(0.1 \%)$ & $0.35 \pm 0.01$ & $0.17 \pm 0.04$ & 2.05 & $3.87 \pm 0.05 *$ & 0.13 & $0.51 \pm 0.01 *$ & $0.04 \pm 0.01 *$ \\
\hline $\mathrm{Cu}^{2+} / \mathrm{PHMG}-\mathrm{Cl}(0.5 \%)$ & $0.41 \pm 0.01 *$ & $0.22 \pm 0.08 *$ & 1.86 & $4.02 \pm 0.02 *$ & 0.15 & $0.57 \pm 0.09^{*}$ & $0.06 \pm 0.02$ \\
\hline $\mathrm{Cu}^{2+} / \mathrm{PHMG}-\mathrm{Cl}(1 \%)$ & $0.31 \pm 0.05$ & $0.13 \pm 0.03 *$ & 2.38 & $1.92 \pm 0.08 *$ & 0.23 & $0.61 \pm 0.01 *$ & $0.09 \pm 0.07 *$ \\
\hline
\end{tabular}




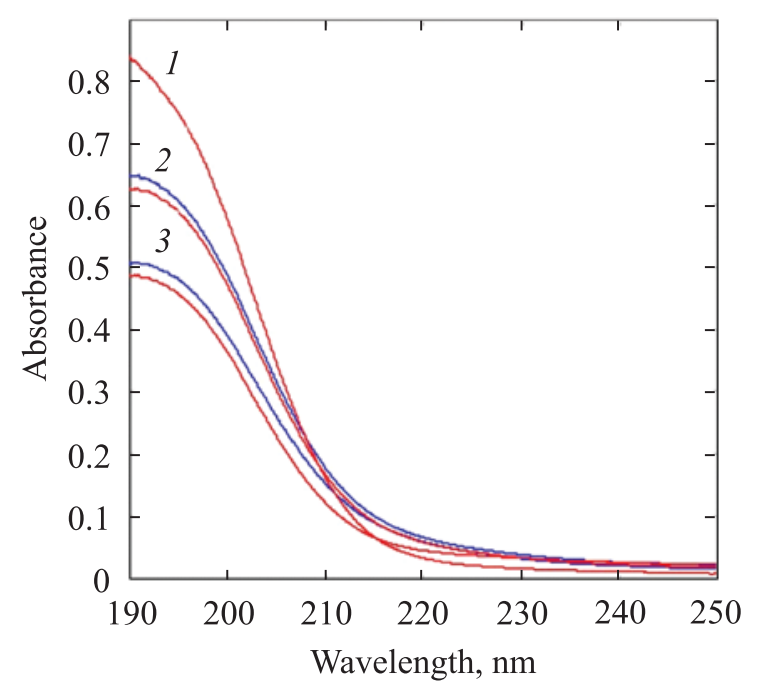

Fig. 2. UV-visible spectra of water solutions: $1-\mathrm{PHMG}-\mathrm{Cl}$ $\left(\mathrm{C}=5 \cdot 10^{-5} \mathrm{~mol} / \mathrm{l}\right), 2-$ mixture of PHMG-Cl $\left(\mathrm{C}=3.4 \cdot 10^{-5}\right.$ $\mathrm{mol} / \mathrm{l})$ and $\mathrm{CuSO}_{4}\left(\mathrm{C}=1.7 \cdot 10^{-5} \mathrm{~mol} / \mathrm{l}\right), 3-$ mixture of PHMG$\mathrm{Cl}\left(\mathrm{C}=2.5 \cdot 10^{-5} \mathrm{~mol} / \mathrm{l}\right)$ and $\mathrm{CuSO}_{4}\left(\mathrm{C}=2.5 \cdot 10^{-5} \mathrm{~mol} / \mathrm{l}\right)$. $*$ Red curve - $\mathrm{PHMG}-\mathrm{Cl}$, blue curve $-\mathrm{PHMG}-\mathrm{Cl} / \mathrm{CuSO}_{4}$ mixture

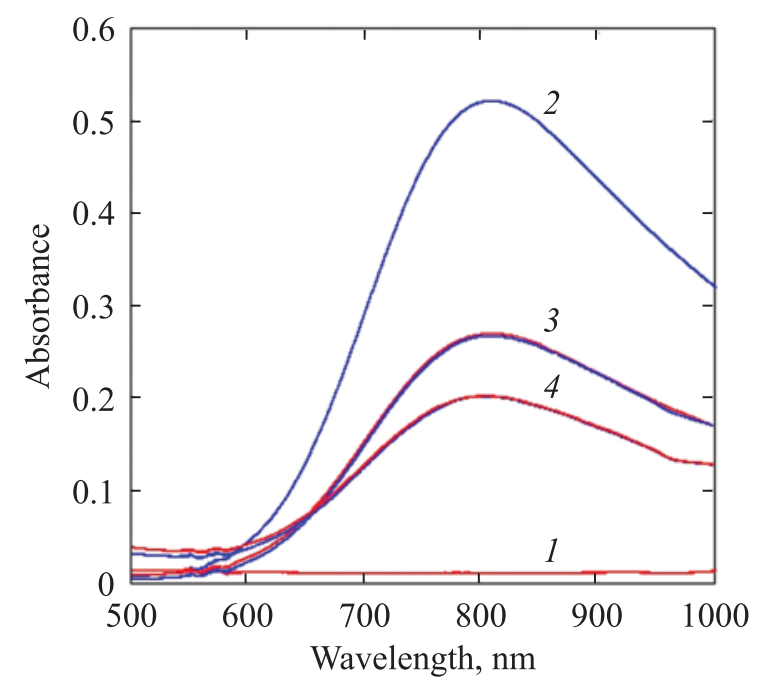

Fig. 3. UV-visible spectra of water solutions: $1-\mathrm{PHMG}-\mathrm{Cl}$ $\left(\mathrm{C}=5 \cdot 10^{-2} \mathrm{~mol} / \mathrm{l}\right), 2-\mathrm{CuSO}_{4}\left(\mathrm{C}=5 \cdot 10^{-2} \mathrm{~mol} / \mathrm{l}\right), 3-$ mixture of PHMG-Cl $\left(\mathrm{C}=2.5 \cdot 10^{-2} \mathrm{~mol} / \mathrm{l}\right)$ and $\mathrm{CuSO}_{4}\left(\mathrm{C}=2.5 \cdot 10^{-2}\right.$ $\mathrm{mol} / \mathrm{l}), 4-$ mixture of PHMG-Cl $\left(\mathrm{C}=3.4 \cdot 10^{-2} \mathrm{~mol} / \mathrm{l}\right)$ and $\mathrm{CuSO}_{4}\left(\mathrm{C}=1.7 \cdot 10^{-2} \mathrm{~mol} / \mathrm{l}\right)$. *Blue curve $-\mathrm{CuSO}_{4}$, red cur$\mathrm{ve}-\mathrm{CuSO}_{4} / \mathrm{PHMG}-\mathrm{Cl}$ mixture (curves 3,4 )

the effect of polymeric biocide on prokaryotic and eukaryotic cells (Lysytsya A et al 2013). High efficiency of cationic polymers against microorganisms is caused by their specific structure, in particular, by the presence of multiple positive charges within a single molecule that are able to compensate the negative charges present on the outer cell membranes of microbes (Carmona-Ribeiro AM, de Melo Carrasco LD 2013).. Due to these strong electrostatic interactions, PHMG is able to attack the cellular envelope, and subsequently associates itself with the head groups of the acidic phospholipids substituting metal cations (magnesium and calcium). The presence of hydrophobic aliphatic chains in the PHMG backbone ensures a better partition to the hydrophobic regions of the phospholipid membranes, resulting in a change of membrane permeability and lethal leakage of cytoplasmic materials (Yang Y et al 2018). Acidic lipids are almost absent in the external monolayer of eukaryotic cells whereas zwitter-ions prevail (phosphatidylcholine, phosphatidylethanolamine, sphingomyelin), that complicates the penetration of cationic biocide through the cellular membrane (Hancock REW, Sahl H-G 2006). Therefore, a probable mechanism of stimulating activity of PHMG-Cl is in the adsorption of polycation onto plant cell membranes, which changes the motility of phospholipids and the regulatory activity of enzymes. This process may be characterized as non-specific adaptation of cells under the impact of polymeric biocide (Lysytsya A et al 2013).

The presence of elevated concentrations of heavy metals in soil is known to inhibit the growth and development of plants due to impairment of the main physiological and metabolic processes (Moustakas M et al 1997, Yruela 2009, Husak V 2015). On the cellular and molecular level, the phytotoxicity of copper ions is manifested in inactivation and denaturation of enzymes and proteins, blocking of functional groups of metabolically relevant molecules, substitution of physiologically relevant metal cations in biomolecules and functional cellular units, conformational modification and alteration of membrane lipid bilayer. In addition, the excess of copper salts in cells impairs the redox homeostasis due to generation of reactive oxygen species- superoxide-anions, hydroxyl radicals, hydrogen peroxide (Rascio N, Navari-Izzo F 2011), causing lipid peroxidation in cells and thus enhancing non-specific permeability of membranes (Berglund AH 2002, Chen J et al 2015). These processes may occur under the impact of $\mathrm{Cu}^{2+}$ ions with the concentration, exceeding $10 \mu \mathrm{mol} / 1$, on plants (Yruela 2009, Riazanova ME et al 2015).

According to the results, presented in Tables 2 and 3 , the solution of copper sulfate with the concentration of $200 \mu \mathrm{mol} / 1$ has negative impact on growth parameters and mass of the roots and shoots of wheat seedlings, as well as on water content in them. The latter may indicate the impairment of water metabolism in plants 
(Rucińska-Sobkowiak R 2016). The pigment content and photosynthetic capacity in plants are known to be dramatically reduced under copper stress conditions (Moustakas M et al 1997, Rascio N, Navari-Izzo F 2011, Adrees $M$ et al 2015). Under experimental conditions, the stress impact of copper ions is manifested in terms of significantly reduced carotenoid content in wheat seedlings, as well as chlorophyll $a$ to $b$ ratio, which influence the photosynthetic capacity of plants. In addition, the content of phenol antioxidants - watersoluble flavonoids - increases in the root part (Table 4). The toxic effect of copper sulfate solution was found to mitigate in the presence of PHMG-Cl. Thus, the growth parameters of wheat seedlings were improved. The water content in plants, as well as the mass of roots and shoots were significantly increased compared to the samples, treated with $\mathrm{CuSO}_{4}$ solution (Table 2, 3). Moreover, the content of plant pigments and flavonoids in the green part restored to the level of control samples (Table 4) which demonstrated the normalization of the biosynthesis.

The results of spectrophotometric studies demonstrated the absence of physico-chemical interaction between $\mathrm{CuSO}_{4}$ and PHMG-Cl. This eliminates the complexation as a possible factor of reducing the negative effect of copper ions on the growth and development of wheat seedlings in the presence of polymeric biocide. It is noteworthy that the polar structure and surface activity of polymeric biocides ensures their efficient adsorption onto cell membranes (Shao Q et al 2012, CarmonaRibeiro AM, de Melo Carrasco LD 2013). Therefore, it can be assumed that PHMG-Cl prevents the accumulation of excessive concentration of $\mathrm{Cu}$ ions in plant cells due to higher membrane activity, including adsorption and diffusion. Antioxidant activity of PHMG-Cl may also be a factor improving copper-stress tolerance in wheat seedlings. Thus, the inhibitory activity of PHMG salt against peroxyl radicals has been established in the model system of initiated oxidation of benzyl alcohol (Rogalskyy SP et al 2012). The authors suggested that polymeric biocide may deactivate free radicals by their complexation with guanidinium cations. The results of subsequent medico-biological studies confirmed the antioxidant activity of guanidine-containing polymers. For instance, the wound-healing effect of a hydrogel based on PHMG-Cl under conditions of thermal shock modeling has been studied (Lebedeva SN et al 2017). It was found that the polymeric biocide activates the growth of antioxidants and leukocytes in the blood of animals, which indicates a pronounced reparative ef- fect. In another study, the effect of PHMG-Cl on the immunological and redox homeostasis indices in blood and skin of rats with non-infected thermal burn, has been studied (Doroshenko A et al 2019). PHMG$\mathrm{Cl}$ was found to have pronounced anti-inflammatory properties and affected redox homeostasis, which is expressed in normalization of the content of markers of free radical oxidation.

Thus, the results of this study indicate the potential availability of the polymeric biocide $\mathrm{PHMG}-\mathrm{Cl}$ as plant growth stimulator. Under toxic effect of copper ions, PHMG-Cl does not possess growth-promoting effect on seed germination and seedlings growth of wheat, but enhances their resistance to stress significantly.

\section{CONCLUSIONS}

The polymeric biocide $\mathrm{PHMG}-\mathrm{Cl}$ demonstrates pronounced growth-promoting effect on wheat seed germination and seedlings growth. Seed treatment with aqueous solutions of PHMG-Cl in the concentration range of $0.01-0.1 \%$ leads to an increase in length of roots and shoots by over $50 \%$ after 7 days of incubation. The concentration of cationic polymer of $1 \%$ inhibits the growth of roots by $22 \%$ and does not impact the growth of shoots compared to control samples. The obtained results indicate significantly lower phytotoxicity of PHMG-Cl (by two orders of magnitude) compared to common copper-based pesticides. Thus, the soaking of wheat seed in $200 \mu \mathrm{M}(0.003 \%)$ aqueous solution of copper sulfate inhibits the growth of shoots and roots by 65 and $34 \%$, respectively, as well as decreases the mass of shoots (by $20 \%$ ) and roots (by $74 \%$ ) The stressful impact of $\mathrm{Cu}^{2+}$ ions on biochemical parameters of wheat seedlings is manifested in terms of reduced content of low molecular antioxidants - flavonoids in the green part of shoots, as well as impairment of the pigment biosynthesis (reduced chlorophyll $a / b$ ratio and carotenoid content).

The toxic effect of copper sulfate solution on wheat seedlings significantly mitigates in the presence of PHMG-Cl. This is manifested in an increased root length and mass (by 64 and $44 \%$, respectively), and shoot length and mass (by 24 and $100 \%$, respectively), as compared with seed samples treated with $\mathrm{CuSO}_{4}$ solution. Moreover, the pigment composition and the $\mathrm{Ca}$ / $\mathrm{Cb}$ ratio restores to the level of control indices that indicates improved plant stress resistance. The results of spectrophotometric investigations showed the absence of complex formation between $\mathrm{CuSO}_{4}$ and PHMG-Cl in aqueous solutions. Based on the obtained results and literature data analysis, it can be assumed that the ad- 
sorption activity and antioxidant properties of PHMG$\mathrm{Cl}$ are the main factors influencing the mitigation of toxic effect of copper ions on wheat seedlings.

Adherence to ethical principles. This article does not relate to any studies using humans and animals as investigation subjects.

Conflict of interests. The authors deny any conflict of interests.

Financing. This study did not receive any specific grant from the financing institutions in state, commercial or non-commercial sectors.

\author{
Вплив полімерного біоциду \\ полігексаметиленгуанідину гідрохлориду \\ на морфофізіологічні та біохімічні параметри \\ проростків насіння пшениці в умовах токсичного \\ забруднення іонами міді \\ Л. Г. Льошина ${ }^{1}$, О. П. Тарасюк ${ }^{2}$, О. В. Булко ${ }^{1}$, \\ С. П. Рогальський ${ }^{2}$, Т. М. Каменєва ${ }^{2}$, М. В. Кучук ${ }^{1}$ \\ ${ }^{1}$ Інститут клітинної біології та генетичної інженерії \\ НАН України \\ вул. Академіка Заболотного, 148, м. Київ, 03143, Україна \\ ${ }^{2}$ Інститут біоорганічної хімії та нафтохімії \\ ім. В. П. Кухаря НАН України \\ Харківське шосе, 50, м. Київ, 02160, Україна \\ e-mail:1lioshina@ukr.net
}

Мета. Встановлення впливу полімерного біоциду полігексаметиленгуанідину гідрохлориду (ПГМГ-Сl) на морфофізіологічні та біохімічні параметри проростків насіння пшениці за присутності токсичної концентрації іонів міді. Методи. Рістстимулюючу активність ПГМГ$\mathrm{Cl}$ у чистому вигляді та за присутності токсичних концентрацій іонів міді досліджували методом фітотестування 3 використанням насіння пшениці як тесткультури. Фізико-хімічну взаємодію між ПГМГ- $\mathrm{Cl}$ i $\mathrm{CuSO}_{4}$ у водних розчинах досліджували спектрофотометричним методом. Результати. Обробка насіння пшениці водними розчинами полімерного біоциду ПГМГ$\mathrm{Cl} 3$ концентраціями 0.01-0.1\% спричиняє збільшення довжини коренів і пагонів проростків більш ніж на 50 \% через 7 діб проростання. Концентрація препарату, при якій відбувається пригнічення росту тест-культури, становить $1 \%$. Це свідчить про значно меншу фітотоксичність ПГМГ-Сl (на два порядки) у порівнянні з традиційним пестицидом сульфатом міді. Під дією водного розчину $\mathrm{CuSO}_{4} 3$ концентрацією 200 мкмоль/л (0.003 \%) зменшується довжина пагонів i коренів проростків (на 65 і $34 \%$ відповідно), а також маса пагонів (на $20 \%$ ) і коріння (на 74 \%). В зеленій частині пагонів встановлено значне зменшення вмісту водорозчинних флавоноїдів (на $37 \%$ ), каротиноїдів (на $26 \%$ ), а також співвідношення хлорофілів $a$ і $b$, яке характеризує ін- тенсивність фотосинтезу (на 18\%). За присутності ПГМГ-Cl $(0.01 \%)$ у розчині $\mathrm{CuSO}_{4}$ токсичний вплив іонів міді на рослини істотно послаблюється. Зокрема, довжина пагонів і коренів збільшується на 24 і 64 \% відповідно, у порівнянні з чистим розчином сульфату міді. Крім того, вміст пігментів і флавоноїдів у зеленій масі проростків відновлюється до рівня контрольних зразків. Результати спектрофотометричних досліджень свідчать про відсутність комплексоутворення між ПГМГ-Сl і сульфатом міді у водних розчинах. Висновки. Полімерний біоцид ПГМГ-Сl ефективно стимулює ріст і розвиток проростків пшениці за концентрацій водних розчинів препарату $0.01-0.1 \%$. За Присутності токсичної концентрації сульфату міді ПГМГ-Сl не проявляє рістстимулюючої активності, однак істотно підвищує стресостійкість рослини, нормалізує іiі морфофізіологічні показники, фотосинтетичні характеристики і вторинний обмін.

Ключові слова: пшениця, полімерний біоцид, полігексаметиленгуанідин, регуляція росту, стресостійкість, фітотоксичність, мідь.

\section{Влияние полимерного биоцида полигексаметиленгуанидина гидрохлорида на морфофизиологические и биохимические параметры проростков семян пшеницы в условиях токсического загрязнения ионами меди \\ Л. Г. Лешина ${ }^{1}$, О. П. Тарасюк ${ }^{2}$, О. В. Булко ${ }^{1}$, С. П. Рогальский ${ }^{2}$, Т. М. Каменева ${ }^{2}$, Н. В. Кучук ${ }^{1}$ \\ ${ }^{1}$ Институт клеточной биологии и генетической инженерии НАН Украины, \\ ул. Академика Заболотного, 148, г. Киев, 03143, Украина \\ ${ }^{2}$ Институт биоорганической химии и нефтехимии им. \\ В. П. Кухаря НАН Украины, Харьковское шоссе, 50, \\ г. Киев, 02160, Украина \\ e-mail: 1lioshina@ukr.net}

Цель. Установление влияния полимерного биоцида полигексаметиленгуанидина гидрохлорида (ПГМГ-Cl) на морфофизиологические и биохимические параметры проростков семян пшеницы в присутствии токсической концентрации ионов меди. Методы. Рострегулирующую активность ПГМГ-Сl в чистом виде и в присутствии токсических концентраций ионов меди исследовали методом фитотестирования, используя в качестве тесткультуры семена пшеницы. Физико-химическое взаимодействие между ПГМГ-Cl и $\mathrm{CuSO}_{4}$ изучали спектрофотометрическим методом. Результаты. Обработка семян пшеницы раствором полимерного биоцида пПГМГ$\mathrm{Cl}$ с концентрациями 0.01-0.1\% вызывает увеличение длины корней и листьев проростков более чем на $50 \%$ через семь суток прорастания. Концентрация препарата, при которой происходит угнетение роста тест-культуры, составляет $1 \%$. Это свидетельствует о значительно более 
низкой фитотоксичности ПГМГ-Сl (на два порядка) в сравнении с традиционным пестицидом сульфатом меди. Под влиянием водного раствора $\mathrm{CuSO}_{4}$ с концентрацией 200 мкмоль/л (0.003 \%) уменьшается длина листьев и корней проростков (на 65 и $34 \%$ соответственно), а также масса листьев (на $20 \%$ ) и корней (на $74 \%$ ). В зеленой части листьев установлено значительное снижение содержания водорастворимых флавоноидов (на $37 \%$ ), каротиноидов (на $26 \%$ ), а также соотношения хлорофиллов $a$ и $b$, характеризующих интенсивность фотосинтеза (на $18 \%$ ). В присутствии ПГМГ-Cl $(0.01 \%)$ в растворе $\mathrm{CuSO}_{4}$ токсическое влияние ионов меди на растения значительно снижается. В частности, длина листьев и корней увеличивается на 24 и $64 \%$ соответственно, в сравнении с раствором чистого сульфата меди. Кроме того, содержание пигментов и флавоноидов в зеленой массе проростков достигает уровня контрольных образцов. Результаты спектрофотометрических исследований свидетельствуют об отсутствии комплексообразования между ПГМГ- $\mathrm{Cl}$ и сульфатом меди. Выводы. Полимерный биоцид ПГМГ$\mathrm{Cl}$ эффективно стимулирует рост и развитие проростков семян пшеницы при концентрациях водных растворов препарата $0.01-0.1 \%$. В присутствии токсической концентрации сульфата меди ПГМГ-Сl не проявляет ростстимулирующей активности, однако существенно повышает стрессостойкость растения, нормализует его морфофизиологические показатели, фотосинтетические характеристики и вторичный обмен.

Ключевые слова: пшеница, полимерный биоцид, полигексаметиленгуанидин, регулятор роста, фитотоксичность, стрессоустойчивость, медь.

\section{REFERENCES}

Adrees M, Ali S, Rizwan M et al. (2015) The effect of excess copper on growth and physiology of important food crops: a review. Environ. Sci. Pollut. Res. doi: 10.1007/ s11356-015-4496-5.

Berglund AH, Quartacci M F, Calucci L. (2002) Alterations of wheat root plasma membrane lipid composition induced by copper stress result in changed physicochemical properties of plasma membrane lipid vesicles. Bioch. Biophys. Acta. Biomembranes. https://doi.org/10.1016/ S0005-2736(02)00498-4.

Carmona-Ribeiro AM, de Melo Carrasco LD. (2013) Cationic antimicrobial polymers and their assemblies. Int. J. Mol. Sci. https://doi.org/10.3390/ijms14059906.

Chen J, Shafi M, Li S et al. (2015) Copper induced oxidative stresses, antioxidant responses and phytoremediation potential of Moso bamboo (Phyllostachys pubescens). Nat. Sci. Rep. doi: 10.1038/srep13554.

Choi H, Kim K-J, Lee DJ. (2017) Antifungal activity of the cationic antimicrobial polymer-polyhexamethylene guanidine hydrochloride and its mode of action. Fungal. Biol. https://doi.org/10.1016/j.funbio.2016.09.001.
Doroshenko A, Gorchakova N, Zaychenko G. (2019) Effect of nanodispersion silica composite with polyhexamethylene guanidine hydrochloride on immunological indicators and indicators of oxidation and antioxidant homeostasis in rats with thermal burn. Scient. J. Sci. Rise: Pharmac. Sci. https://doi.org/10.15587/2519-4852.2019. 178951.

Filonik IA, Aprasjukhin AI. (2008) Stimulator for growth and development of crops and method to stimulate growth and development of corn and wheat. RU 2328854C2. 20 July 2008.

Hancock REW, Sahl H-G. (2006) Antimicrobial and hostdefense peptides as new anti-infective therapeutic strategies. Nat. Biotechnol. doi: 10.1038/nbt1267.

Husak V. (2015) Copper and copper-containing pesticides: metabolism, toxicity and oxidative stress. JPNU. doi: 10.15330/jpnu.2.1.38-50.

Prasad MNV, Strzalka K. (2002) Physiology and biochemistry of metal toxicity and tolerance in plants. Kluwer Academic Publishiers, 448pp.

Lamichhane JR, Osdaghi E, Behlau F et al. (2018) Thirteen decades of anti-microbial copper compounds applied in agriculture. A review. Agron. Sustain. Dev. doi: 10.1007/ s13593-018-0503-9.

Lebedeva SN, Ochirov OS, Stelmakh SA et al. (2017) Wound healing effect of polyhexamethylene guanidine hydrochloride hydrogel at burns. Acta Biomed. Sci. https:// doi.org/10.12737/article_59fad51d481658.42549272. Lichtenthaler HK. (1987) Chlorophylls and carotenoids: pigments of photosynthetic biomembranes. Meth. Enzymol. https://doi.org/10.1016/0076-6879(87)48036-1.

Lioshyna L, Bulko O, Litvinov S et al. (2017) X-ray exposure to the stress response from $R i$-transformed regenerants Digitalis purpurea L in vitro. Rad. J. http://doi:10.21175/ RadJ.2017.01.001.

Lysytsya A, Lyco S, Portuhaj O. (2013) The polyhexamethyleneguanidine stimulation of seeds growing and cell proliferation. J. Mater. Sci. Eng. doi: 10.17265/21616221/2013.10.004.

Lysytsya AV, Mandygra YM, Bojko OP et al. (2015) Differential sensitivity of microorganisms to polyhexamethyleneguanidine. Mikrobiol. Z.https://doi.org/10.15407/ microbiolj77.05.011.

Lysytsya A, Matvienko N, Kozii M et al. (2017) Influence of polymeric derivatives of guanidine on hydrobionts. Biologija. https://doi.org/10.6001/biologija.v63i3.3582.

Lysytsya AV. (2017) Research on the impact of polyhexamethyleneguanidine on the plant component of biocenoses. Biosyst. Divers. https://doi.org/10.15421/011713.

Moustakas M, Ouzounidou G, Symeonidis L et al. (1997) Field study of the effects of excess copper on wheat photosynthesis and productivity. Soil. Sci. Plant. Nutr. doi: 10.1080/00380768.1997.10414780.

Olmedo GM, Cerioni L, Sepulveda M et al. (2018) Polyhexamethylene guanidine as a fungicide, disinfectant and 
LYOSHYNA et al.

wound protector in lemons challenged with Penicillium digitatum. Food Microbiol. https://doi.org/10.1016/j. fm.2018.03.018.

Pätsikkä E, Kairavuo M, Šeršen $F$ et al. (2002) Excess copper predisposes photosystem II to photoinhibition in vivo by outcompeting iron and causing decrease in leaf chlorophyll. Plant physiol. https://doi.org/10.1104/ pp.004788.

Protasov A, Bardeau JF, Morozovskaya I et al. (2016) New promising antifouling agent based on polymeric biocide polyhexamethylene guanidine molybdate. Environ. Toxicol. Chem. https://doi.org/10.1002/etc.3782.

Rascio N, Navari-Izzo F. (2011) Heavy metal hyperaccumulating plants: how and why do they do it? And what makes them so interesting? Plant Sci. https://doi.org/10.1016/j. plantsci.2010.08.016.

Riazanova ME, Makoveuchuk TI, Schwartau VV. (2015) Effect of $\mathrm{Cu}^{2+}$ and $\mathrm{pH}$ on intracellular calcium content and lipid peroxidation in winter wheat roots. Biosyst. Divers. doi: https://doi.org/10.15421/011512.

Rucińska-Sobkowiak $R$. (2016) Water relations in plants subjected to heavy metal stresses. Acta Physiol. https:// doi.org/10.1007/s11738-016-2277-5.

Rogalskyy SP, Kameneva TM, Bardeau J-F et al. (2012) Antimicrobial polymeric composition based on polyamide 12 and poly(hexamethylene)guanidine dibutylphosphate. Catal. Petrochem. http://nbuv.gov.ua/UJRN/ KiN_2012_20_11.

Sharma A, Shahzad B, Rehman A et al. (2019) Response of phenylpropanoid pathway and the role of polyphenols in plants under abiotic stress. Molecules. https://doi. org/10.3390/molecules24132452.
Shao Q, Fan Y, Yang L et al. (2012) Counterion effects on the denaturing activity of guanidinium cation to protein. J. Chem. Theor. Comput. doi: 10.1021/ct3002267.

Wang H, Ebenezer V, Ki J. (2018) Photosynthetic and biochemical responses of the freshwater green algae Closterium ehrenbergii Meneghini (Conjugatophyceae) exposed to the metal coppers and its implication for toxicity testing. J. Microbiol. https://doi.org/10.1007/s12275-0188081-8.

Wei D, Zhou R, Guan Y et al. (2013) Investigation on the reaction between polyhexamethylene guanidine hydrochloride oligomer and glycidyl methacrylate. J. Appl. Polym. Sci. https://doi.org/10.1002/app.37849.

Xia X, Shen ZG. (2007) Comparative studies of copper tolerance and uptake by three plant species of the genus Elsholtzia. Bull. Environ. Contam. Toxicol. https://doi. org/10.1007/s00128-007-9222-7.

Yang Y, Cai Z, Huang Z et al. (2018) Antimicrobial cationic polymers: from structural design to functional control. Polym. J. https://doi.org/10.1038/pj.2017.72.

Yessimova OA, Adilbekova AO, Kerimkulova MZh et al. (2018) Influence of mixed aqueous solutions of polyhexamethylene guanidine hydrochloride and PO-10 on vegetable crop seeds. Int. J. Biol. Chem. https://doi. org/10.26577/ijbch-2018-2-324.

Yruela I. (2009) Copper in plants: acquisition, transport and interactions. Funct. Plant Biol. https://doi.org/10.1071/ FP08288.

Zhou Z, Wei D, Guan Y et al. (2011) Extensive in vitro activity of guanidine hydrochloride polymer analogs against antibiotics-resistant clinically isolated strains. Mater. Sci. Eng. https://doi.org/10.1016/j.msec.2011.08.015. 